\title{
The Quest for Success and Power in F. Scott Fitzgerald's Novel The Beautiful and Damned
}

\author{
Ala Eddin Sadeq \\ Zarqa University, Jordan \\ E-mail: alaeddin_english@zu.edu.jo
}

Doi:10.7575/aiac.alls.v.8n.1p.181

URL: http://dx.doi.org/10.7575/aiac.alls.v.8n.1p.181
Received: $21 / 11 / 2016$

Accepted: 07/02/2017

This research is funded by the Deanship of Scientific Research at Zarqa University-Jordan.

\begin{abstract}
This study aims at investigating the concepts of success and power, as depicted by F. Scott Fitzgerald in The Beautiful and Damned (2009). Cultural change motivates individuals to work harder to achieve success, which in turn makes them influential. The study reveals that the concepts of success and power are controversial, as their means vary from one theorist to another. Waldo Emerson, for example, believes that success is connected to happiness. He, therefore, lists down features that characterize successful people. To succeed, one must learn to follow their desires, an argument that is expounded by the ideology of the American Dream. Friedrich Nietzsche, however, explains that individuals are motivated to lead due to the fact that power brings about the superman. To achieve the status of the superman, Nietzsche believes that individuals develop the will to power and are able to influence others (Nietzsche, 1968). Fitzgerald, on the other hand, makes it clear that power leads to liberty. The novel provides a deep analysis of the quest for power and success. The main characters are Gloria, Joseph, and Anthony who helps to demonstrate the quest for success and power. Richard Caramel is also a character whose role explains the pursuit of true happiness. He is depicted as powerful because he influences the society through his writings. He has a strong determination to be a writer, which motivates him to work hard and to seek further success.
\end{abstract}

Keywords: The Beautiful and Damned, Fitzgerald, power, success, super-human, individuals, happiness

\section{Introduction}

Success and power are problematic concepts that have gained prominence in several critical and philosophical works. What makes such concepts intricate is their relativity, as they cannot be restricted to fixed definitions. Nevertheless, people constantly struggle to achieve power and success, as they believe that these are ultimate purposes that can be reached in one way or another through a long quest of hard work. Unexpectedly, the quest for success and power might lead to misery and failure despite of the individual's struggle for self-fulfillment.

This study aims at showing how the quest for success and power could fail due to the lack of seriousness and the incapability of having an insightful plan to life. This means that realizing success and power is not a facile task; it rather requires going through a long quest of hard work.

This study is theoretical and analytical. It applies the theories of success and power, which are discussed by Waldo Emerson, John Locke and Friedrich Nietzsche, to Fitzgerald's novel The Beautiful and Damned (2009). The novel is about an American couple who seeks success and power, but fails to realize their purpose, as they are obsessed in a life of leisure. As a result, the couple loses their money and their purpose.

The novel uses the progression of the author's intense love based on the dazzlingly beautiful Gloria Gilbert. It's a story that does trace the attachment of a couple through their marriage and courtship, despite their endless round of gaiety and parties in relation to their financial challenges. Though Emerson believes that successful and powerful people are happy, the main characters in the novel are not. The study offers a positive contribution to matters of quest towards power and success. Adam realizes that his grandson is a drunkard, he decides to donate his share of inheritance to charity due to the economic power he has over Anthony. The most important aspect of power brought up by the author is the need to be self-reliant and to follow one's dreams. Emerson indicates that the laughter should be often or long lasting to succeed; he says: "To laugh often and much ... this is to have succeeded" (Prasad, 2006 p. 354). Anthony's obsession with imaginary happiness is indicated by drinking, "the pawnshops would remain open until late Saturday nights, and he felt that if he took just one more drink he would attain a gorgeous rose-colored exhilaration," (Fitzgerald, 2009 P.352). Emerson argues that success is the tendency to appreciate others. Linda Carter comments on Emerson by saying that "[h]e has achieved success who has lived well, laughed often and loved much; who has gained the respect of intelligent men" (Carter 2016 p. 110). 


\section{Discussion}

\subsection{The Quest for Success}

The quest for success is concerned with the extent to which individuals are able to achieve their desires, and it varies from one culture to another. However, the high interaction and well developed communication among people from different cultures has led to the development of a more universal definition of success. The level of success of individuals in the society today is indicated by their economic achievement and their pursuit for knowledge. Based on these expectations, successful individuals are highly respected in the society and the recognition acts as a motivating factor. On a personal level, success may be defined by one's ability to achieve personal goals that may not necessarily relate to economic achievement. It is defined by personal development, a long process that leads to the acquisition of qualities that maximize an individual's potential. Eventually, personal development leads the individuals to pursue knowledge, gain high economic status and recognition in the society.

The American Dream is one of the concepts that relate to success, which refers to the economic, social and political expectations of individuals. The concept holds that success or achievements in life are gained by working hard towards specific goals (Izaguirre, 2014). It encourages people that it is possible to be wealthy, even when one comes from a poor economic background. The variation in success among individuals is closely linked to their hard work and commitment towards achieving the set objectives. Apart from wealth, success is also defined by the height of social order in the society. The American Dream is about achieving a society where social inclusion is highly valued; where individual differences do not hinder people from actualizing their potential. The pursuit of happiness is one of the foundations of the American Dream, implying that success can be measured by the extent to which one is happy. For example, an individual who is wealthy and sad is not successful because he is unhappy. The other foundation of the American Dream is the state of being free from any restrictions. Liberty is among the aspects that enhance creativity and personal development, which in turn leads to achievement of success.

The link between success and happiness is described by John Locke, who argues that wealth, pleasure and general satisfaction with life are brought about by happiness (Charles, 2011). However, success he points out that happiness may be real or imagined, and that success is not achieved through imagined happiness. Apart from happiness, liberty is the other aspect that influences the ability of individuals to achieve success. Locke explains that happiness is a premise of liberty thus an indirect cause of happiness "We have a power to suspend the prosecution of this or that desire. . . This seems to me the source of all liberty; in this seems to consist that, which is (as I think improperly) call'd Free will" (Locke, 1894 p.155). In his opinion, the effort by individuals to pursue happiness leads to their liberty and hence the ability to actualize their aspirations. Liberty enhances the ability of individuals to make decisions that are geared towards achieving success (Pearlstein, 2012). The primary emphasis that Locke has on success is that people must seek true happiness because it develops the desire needed to achieve success. As opposed to imaginary happiness, real happiness brings about lasting satisfaction. Locke concludes that success is only achieved through liberty, only if it leads individuals to make decisions about long-term pleasure or true happiness.

Ralph Waldo Emerson's literature also links success to happiness, suggesting that success is measured by the extent to which an individual is happy (Emerson, 2005). He cites that successful people laugh more, indicating that success is related to happiness. He further contends that success is defined by the amount of respect that one commands from the society due to their achievements, an argument similar to the American Dream (Ştiuliuc 2011). Both arguments agree that success leads to achievement of recognition and this is what motivates individuals to work even harder. Emerson also argues that success is achieved by individuals who use constructive criticism from other to make their lives better. Such individuals recognize the best time to end negative influences in their lives as they are solid barriers to success. Self-development is another aspect that leads one to lead a successful life, according to Emerson. It is enhanced by the commitment of individuals to strive to be better than they were before.

\subsection{The Modern Spirit of Searching for Power}

The desire to influence other people's actions is among the factors that motivate the search for power. One of the manifestations of power is soft power, or the ability to influence other individuals to change their preferences. This is the type of power that is mainly used by successful business, where the management team applies the power to influence the employees to follow objectives that impact organizational success positively (Irwin, 2013). Communitybased policies in the contemporary world are also implemented using soft power. The primary advantage associated with soft power is that the chances of resistance are low. Leaders who use soft power have an easy time influencing the followers compared to other methods of power that are dictatorial. The other manifestation of power is blatant coercion, which entails the use of force to influence others. Commonly found in political setting, blatant coercion is effective as the followers are forced to obey. However, regardless of the type of power that individuals seek, the spirit of searching for power is uniform.

Power and wealth are two variables that are closely related because the former is linked to the ability of individuals to make decisions that lead to economic success. Further, power enables individuals to block or acquire forces that bring about wealth. The other aspect that is linked to power is realism due to the sense of security created by power. Individuals who are in power or control know that they cannot be influenced by the followers thus develop realistic visions. Power brings about self-satisfaction and guarantees happiness in life. The positive aspects of power are the primary reasons that drive individuals to seek power. Therefore, people seek power for realism and wealth. Trends of individuals searching for power can be observed in different situations such as in battles. The primary reasons that 
individuals unite to form an army during wars is to increase their influence or power relative to the other team. The positive relationship between power and success is the primary reason that creates the will to power, a concept developed by Friedrich Nietzsche (1968).

Following his deep interest in searching for power, Nietzsche develops insights about the reasons that motivate individuals to search for power. He asserts that human nature motivates individuals to seek power because it allows them dominance over others. "The will to power in every combination of forces, defending itself against the stronger, lunging at the weaker, is more correct" (Nietzsche 1968 p. 346). One of the historical examples of dominance that Nietzsche explains is slavery. The colonial masters had perfected the will to power and they used means such as religion to influence obedience of slaves. The oppression of slaves by the powerful individuals was termed as humility and obedience, which were important values among the Christians. Nietzsche also explains that slavery succeeded because the people did not have the will to power the slaves did not intend to change their status as they were satisfied with submission. In his opinion, submission to the values held or proposed by other people is wrong as it denies one the ability to express their super-human nature. One of the factors that characterize power is the ability of individuals to be supermen, which is determined by the extent to which they formulate their personal goals and follow them consistently.

The strong will to power among individuals is among the factors that frustrated political ideologies such as classical liberalism. The ideology allowed individuals to express themselves freely and there was limited governance. However, the ideology failed although it was meant to enhance the common good of individuals. The desire for individuals to seek for power led to the emergence of political leaders who influenced the society against classical liberalism (Karp, 2009). The collapse of American Dream is also a factor that can be linked to the pursuit of power by individuals. The American Dream intended to create a society where everyone has equal chances of success in life regardless of factors such as race or economic status. However, this is not achievable because people have varying will to power. There are those who are satisfied with submission to other people's values, and there are others who influence others to follow their values.

\subsection{Cultural Change}

The perceptions that people hold about different aspects of life are greatly influenced by their culture. Therefore, the ability to influence people to change their perceptions can only be achieved through cultural change. Presently, the high interactions among people from diverse backgrounds across the world have enhanced the acceptance of cultural diversity among people. Cultural change is related to the ability of individuals to achieve success in their lives as they embrace new ways that may be more productive. The principle of social inclusion is among the factors that encourage cultural change within a society, and this leads to success. Emerson argues success is the tendency to appreciate others. Carter comments on Emerson by saying that "He has achieved success who has lived well, laughed often and loved much; who has gained the respect of intelligent men" (Carter 2016 p. 110). To achieve this, individuals must change their negative perceptions about other people or groups of people (Adger et al., 2013). The success of American Dream was based on the hope that the society would be more accommodative of immigrants and people from poor economic backgrounds. The ideology aimed at creating a society that enhanced the ability of all individuals to succeed. However, it was successful because of cultural rigidity that promoted vices such as racial and gender bias at the workplace. For the American Dream to be successful there was a need to create awareness about the importance of equality.

One of the success factors in life is cultural change because it gives individuals different perspectives about situations. It allows people to rise above their fears because they develop alternative options to conduct activities that would otherwise be considered unachievable. The argument about superman developed by Nietzsche is a reflection of cultural change because it leads to the self-development (Biglan \& Embry, 2013). Individuals who have accepted cultural change are able to formulate personal values that they follow in life instead of submitting to the values of others. Cultural change also enhances the will power of individuals by enabling them to be more ambitious in achieving their goals. It gives individuals the confidence they need to change the factors that may limit their success. There are various reasons that lead to cultural change in the society and they are closely related to achievement of success (Tate, 2007). One of the factors that promote the changes is environmental developments such as technological advancements and economic factors. The type of leadership adopted by the society is the other aspect that promotes cultural change. Changes in the society are greatly influenced by the impact that the leaders have on the followers.

The arrogance and self-obsession shown by the main characters in the novel The Beautiful and Damned by F. Scott Fitzgerald helps in developing themes of success, power and cultural change (Fitzgerald, 2009). The lack of personal development and low will to power hinders the ability of the characters to succeed in life. Anthony, one of the main characters, is presented with an arrogant behavior that hinders his ability to be successful in life (Apriliyani, 2014). He believes that the wealth that his family owns makes him powerful, thus has no will to power. The sense of selfimportance that Anthony shows results from his hope that he is wealthy only to learn that he is not among the beneficiaries of his family's estate. The other main character who is presented as arrogant is Gloria, because she is only concerned with getting married to a rich man. Her self-obsession is shown by the belief she holds that all she needs to succeed is beauty. Gloria's will to power is also hindered by her misled perception that she is powerful because of her beauty. The character's arrogance acts as a barrier to their success, leading them to misery. They are only able to achieve imaginary happiness, which does not last long. 
In the novel The Beautiful and Damned by F. Scott Fitzgerald, it is clear that there is a strong connection between power and success (Fitzgerald, 2009). The concept of power is indicated by the influence that the characters have on others and the perceptions they hold regarding aspects such as beauty. The power that Anthony has is the wealth that he expects to gain from inheritance from his wealthy grandfather Dick. Although Anthony is not very wealthy, he is able to tempt Gloria to marry him. Gloria on the other hand, holds a perception that her power is lies in her beauty and believes it is through this power that she can influences Anthony to marry her, for "her beauty was cool as this damp breeze, as the moist softness of her own lips" (Fitzgerald 2009 p. 85). The perceptions that the two characters have about power are inaccurate and this affects their success. According to Fitzgerald, power influences success because it allows individuals to make decisions that affect their lives positively. Apart from money, the other manifestation of power is knowledge or education (Kesebir \& Diener, 2009). When Anthony learns that he is not going to receive any inheritance, he asks for help from Joseph Bloeckman who had succeeded in life due to hard work. This implies that for one to succeed in life, they need to work hard (Min \& Kim, 2013). The concepts of power and success discussed by Fitzgerald relate with other concepts that have been developed over the decades. The discussion below applies the different concepts that relate to power and success as developed in the novel.

\subsection{Definition of Power and Success}

The concept of success as described by Fitzgerald is closely related to Emerson's view of success. Though Emerson believes that successful people are happy, the main characters in the novel are not. Emerson indicates that the laughter should be often or long lasting to succeed he says that: "To laugh often and much ... this is to have succeeded" (Prasad, 2006 p. 354). Fitzgerald describes the pleasure sought by Anthony and Gloria as short-lived; Anthony indicates that "Things are sweeter when they're lost. I know - because once I wanted something and got it. It was the only thing I ever wanted badly. And when I got it turned to dust in my hands" (Fitzgerald, 2009 p. 279). The happiness of the couple only lasts when there is hope for wealth, but when they face the reality of poverty they are always fighting.

The other aspect of success described by Emerson is that successful people are respected by the intelligent people in the society (Emerson, 2005). This indicates that success leads to recognition of individuals in the society. In the novel, Fitzgerald describes the rejection of Anthony by his grandfather instead of being recognized. The decisions made by Anthony leads to his failure and he is despised even by his own family (Kesebir \& Diener, 2009). Personal development is the other feature that characterizes success, as indicated by Emerson (Emerson, 1904). In the novel, Bloeckman embraces personal development by working hard to succeed. On the other hand, Anthony and Gloria do not see the need to develop their abilities because they believe that they already have the power needed to succeed. Anthony claims that he can write but uses most of his time pursuing short-lived pleasure, while Gloria does not see the need for personal development because she has the beauty needed for success.

Emerson explains that successful individuals affect the world positively through their actions. Brown argues that: "Everyman [successful man] is a hero and an oracle to somebody, and to that person, whatever he says has an enhanced value" (Rob 2007 p. 183), as shown by Adams Patch in the novel. Fitzgerald uses the character to show that successful individuals make sound choices. Based on the characteristics of successful people as indicated by Emerson, it is clear that Adams Patch is successful (Kitayama \& Markus, 2000). Adams leaves the world a better place after passion on because he donates his wealth to the needy, another sign that depicts him as a successful person. Further, Emerson explained that successful people have a positive perception about others (LeBlanc, 2007). In the novel, it is clear that Gloria is unsuccessful as indicated by the comment she makes that she prefers having male friends to female ones "she had conceded vaguely to herself that all the men who had ever been in love with her were her friends" (Fitzgerald, 2009 p. 297) as men are superficial. Successful people are also able to face betrayal by their friends. In the novel, Fitzgerald explains that Bloeckman offers to help Anthony even after he mistreated him in the past.

The concept of power relates to the interactions of individuals, where those in power influence the behavior of others. This is mostly observed in learning institutions, businesses and any other situation where leadership is needed to influence the actions of others. There are also cases where power is linked to knowledge and economic status, as depicted in the novel (Min \& Kim, 2013). Fitzgerald explains the misconception about power held by Anthony where he imagines that his wealthy grandfather would make him a powerful man through inheritance. Gloria has the same misguided notion about power because she believes in her beauty. The power of wealth is indicated by the actions taken by Adams when he decides to donate some of his wealth to charity (Cochoy, 2005). Fitzgerald makes it clear that power leads to liberty. Richard Caramel is also depicted as powerful because he influences the society through his writings. The short stories that he writes are developed into movies and they appeal to a large audience.

\subsection{Pursuit of Success and Power}

The concept of success as indicated by Fitzgerald is influenced by the type of happiness sought by individuals. In the hope that he would receive inheritance upon his grandfather's death, Anthony did not care to develop his skills and instead he used the little family income to finance temporary pleasures. Gloria was also concerned about short-lived pleasures as indicated by the number of men that she had dated as mentioned in her diary and the statement by the author that she was a flirt. Together, the young couple spent most of their time having fun. Based on Locke's argument, the characters were bound to fail in life because they concentrated on seeking imaginary pleasure or happiness (Derber, 2000). Locke cites the dangers of pursuing imaginary happiness, arguing that it is very temporary and does not last long (Locke, 1894). Fitzgerald's view of success is consistent with Locke's concept. Both authors agree that pleasure is 
important in life, but it depends on the type of happiness that individuals seek. The authors agree that the pursuant of true or real happiness is the key to success. In opposition to pursuit of imaginary happiness, Anthony's grandfather removes his name from the list of the heirs due to the fact that he was a drunkard. Fitzgerald shows an example of benefits of pursuing true happiness through Bloeckman's success, which is achieved through hard work and commitment. Bloeckman pursues true happiness that improves his economic status.

According to Locke, true happiness leads to overall success in life for the individuals. In the novel, Fitzgerald clearly shows that Anthony and Gloria are not interested in seeking true happiness based on the fact that the pleasure they sought did not lead to complete satisfaction of their lives (Locke, 1894). Anthony's obsession with imaginary happiness is indicated by drinking, "the pawnshops would remain open until late Saturday nights, and he felt that if he took just one more drink he would attain a gorgeous rose-colored exhilaration," (Fitzgerald, 2009 P.352). besides drinking Anthony believes that money leedes to happiness and success as tool to buy drinks. He says that also by money "I left my money on the dresser at home. And I wanted to buy you another drink." (Fitzgerald, 2009 P.352). On the contrary, the happiness pursued by Bloeckman is true because he leads a happy and satisfied life where his financial status is high. The pursuant of happiness by Bloeckman exemplifies the argument by Locke that real happiness is the reason that people make sound decisions due to liberty (Derber, 2000). He uses the liberty gained from pursuing happiness to make the decision to work hard for success and he achieves it.

In the case of Anthony and Gloria, their pursuit for imaginary happiness leads to their misery because they make poor choices that affect their willingness to work towards personal development. Anthony would wait for some path of hope, some purpose yet to be born. He is aimless and depressed; he is obsessed with happiness. The narrator of the novel says that: "it was a self-absorption with no comfort, a demand for expression with no outlet, a sense of time rushing by, ceaselessly and wastefully- assuaged only by the conviction that there was nothing to waste, because all effort and attainments were equally valueless." (Fitzgerald, 2009 P.77). It is evident that the liberty gained by pursuing imaginary happiness is not helpful in decision-making as depicted through the characters of Anthony and Gloria. The concept of pursuit of happiness is also shown by Adam Patch, through his decision to contribute positively to the society through charity work as in encouraged Anthony to define an aim that should lead him to some accomplishment.

"Now that you are here you ought to do something" said his grandfather softly, "accomplish something."

Anthony waited for him to speak of "leaving something done when you pass on." Then he made a suggestion: "I thought-it seemed to me that perhaps I'm best qualified to write--"

Adam Patch winced, visualizing a family poet with long hair and three mistresses.

"—history," finished Anthony.

"History? History of what? The Civil War? The Revolution?"

"Why_no sir. A history of the Middle Ages." (Fitzgerald, 2009, p. 14)

The philanthropic activity brings him joy and he prefers donating his wealth for charity rather than give it to his drunkard grandson. Richard Caramel is also a character whose role explains pursuit of true happiness. His strong determination to be a writer motivates him to work hard and he takes notes anytime he finds something inspiring. His pursuit for happiness proves to be beneficial when he publishes his first book that sells well.

Due to the perceived benefits of power, individuals are always seeking to dominate over others especially in economic and social aspects. Everyone strives to be better than the others and this is human nature, as explained by Nietzsche (Judge \& Kammeyer-Mueller, 2011). Nietzsche explains that individuals develop the will to power, which enables them to accomplish their set objectives (Nietzsche 2011). In the novel, the will to power is indicated by Caramel's commitment to writing a book. He intends to achieve his superman goal by being the best writer ever and he achieves his will to power. Emerson also argues that individuals have to strive hard to become powerful. He says that individuals should work towards being the best at what they do because in the end they become powerful. In his opinion, power is the end of hard work but not the means. It is thus crucial for individuals to ensure that they work towards being powerful through success (Emerson 2005). Emerson's concept of power is supported by Fitzgerald through Anthony, who fails to succeed in life because he considers power as a means to an end instead of the end. Anthony claims "I don't care about the truth, I want some happiness" (Fitzgerald, 2009 P.252). He is educated and has a lot of opportunities to develop his abilities for future benefit, but instead he decides to spend the allowance given to him by his grandfather on alcohol with hope that he would be rich in the future. Cultural change plays a vital role in pursuit of power as it allows individuals to achieve their dreams efficiently (Swartz, 2012). It enables them to be more aggressive in pursuit of power and success. The change acts as the motivation for individuals to strive more for success.

\subsection{The link between Liberty, Power and Success}

Liberty refers to the sense of freedom and independence, which gives individuals the power to act as they wish. The link between liberty and success is clear, as indicated by the way the characters use the freedom they have to make choices. Abuse of liberty as indicated by Anthony and Gloria's decision to pursue pleasure hinders their ability to succeed in life. In the same way, Bloeckman uses liberty to make the right decision and achieves great success. The concept of liberty is well explained by the American Dream, which proposes the creation of a society where everyone is 
self-reliant (Min \& Kim, 2013). The liberty offered by the American Dream aimed at promoting individuals' pursuit of happiness. This implies that individuals have the freedom to make decisions about pleasure. The variation in the level of success by individuals is mainly influenced by the decisions they make about pursuit of happiness. According to Locke, liberty brings about success because it detaches individuals from activities that are detrimental to their success (Locke, 1894).

The concept of power is closely related to the independence that individuals have to make decisions that impact their lives positively (Hinshelwood, 2013). Emerson believes that human beings are at liberty to make life decisions. He argues that the biggest accomplishment for humanity is following one's dreams. He also explains that individuals are free to choose whether to follow their rules or submit to other people's rules, arguing that the greatest achievement is following one's rules (Kienker, 2009). Nietzsche agrees with Emerson's argument, citing the importance of establishing personal goals. The authors link power to the liberty to make personal rules, and explain that it leads to self satisfaction. Nietzsche argues that people have a super-human nature, that is only expressed when they stop submitting to other people's values and instead develop their own. The desire to be superman by accomplishing the goals is what drives people towards success. Nietzsche also referrers to the strong desire to accomplish things through the will to power (Nietzsche, 1968).

\section{Conclusion}

It is evident that success is not guaranteed by one's current economic background, but their commitment to selfdevelopment. The importance of self-reliance in life's success journey is crucial, as indicated by the consequences faced by Anthony due to overreliance on inheritance. If Anthony had been self-reliant, he would not be affected by his grandfather's decision to deny him a share of his wealth. The importance of hard work in success is depicted by the influence that Caramel has on the society from short stories. Based on Emerson's description of successful individuals, it is possible for one to determine whether they are successful and work towards achieving the best in life.

The strong link between power and success is comprehensively covered by Fitzgerald through the characters. One understands the importance of striving to achieve the superman status described by Nietzsche, through the success achieved by Caramel. He obtains power through his success in writing a book, which results from his hard work. The link between power and liberty is also well explained in the novel, where powerful individuals have the freedom to make their decisions. When Adams realizes that his grandson is a drunkard, he decides to donate his share of inheritance to charity due to the economic power he has over Anthony. The most important aspect of power brought up by the author is the need to be self-reliant and follow one's dreams. People have varying aspirations and as Emerson explains, the greatest achievement is one's ability to define and follow their own rules.

\section{References}

Adger, W. N., Barnett, J., Brown, K., Marshall, N., \& O'Brien, K. (2013). Cultural Dimensions of Climate Change Impacts and Adaptation. Nature Climate Change, 3(2), 112-117.

Apriliyani, d. (2014). Hedonism Reflected in The Beautiful and Damned Novel by F. Scott Fitzgerald. Jurnal Ilmiah Mahasiswa FIB, 6(4).

Biglan, A., \& Embry, D. D. (2013). A Framework for Intentional Cultural Change. Journal of Contextual Behavioral Science, 2(3), 95-104.

Brown, R. (2007). How to Build Your Reputation: The Secrets of Becoming the Go to Professional in a Crowded Marketplace. Ecademy Press.

Carter, L. (2016). What I Need 2 Succeed: From A to Z for Teens. Morgan James Publishing LLC.

Charles, P. J. (2011). Restoring Life, Liberty, and the Pursuit of Happiness in Our Constitutional Jurisprudence: An Exercise in Legal History. Wm. \& Mary Bill Rts. J., 20, 457.

Cochoy, N. (2005). New York as a "Passing Stranger" in The Beautiful and Damned. The F. Scott Fitzgerald Review, 4(1), 65-83.

Derber, C. (2000). The Pursuit of Attention: Power and Ego in Everyday Life. Oxford University Press.

Emerson, R. W. (2005). The Art of Successful Living. Sterling Publishers Pvt. Ltd.

Emerson, Ralph Waldo, and Larzer Ziff (2003). Nature and Selected Essays. New York: Penguin, Print.

Fitzgerald, F. S. (2009). The Beautiful and the Damned. The Pennsylvania State University Press

Henry Bamford Parkes (1953), The United States of America: A History ( New York: Alfred A. Knopf, Inc.

Hinshelwood, B. (2013). The Carolinian Context of John Locke's Theory of Slavery. Political Theory, 41(4), $562-590$.

Irwin, W. (2013). Superman and Philosophy: What Would the Man of Steel Do (Vol. 82). M. D. White (Ed.). John Wiley \& Sons.

Izaguirre, J. (2014). The American Dream and Literature: How the Themes of Self-reliance and Individualism in American Literature are Relevant in Preserving Both the Aesthetics and the Ideals of the American Dream.

Judge, T. A., \& Kammeyer-Mueller, J. D. (2011). Happiness as a Societal Value. The Academy of Management Perspectives, 25(1), 30-41. 
Karp, L. N. (2009). Truth, Justice, and the American Way: What Superman Teaches us about the American Dream and Changing Values within the United States.

Kesebir, P., \& Diener, E. (2009). In Pursuit of Happiness: Empirical Answers to Philosophical Questions. In The Science of Well-being (pp. 59-74). Springer Netherlands.

Kienker, J. B. (2009). A Peculiar Felicity of Expression: The Pursuit of Happiness and the American Founding. The Claremont Graduate University.

Kitayama, S., \& Markus, H. R. (2000). The Pursuit of Happiness and the Realization of Sympathy: Cultural Patterns of Self, Social Relations, and Well-being. Culture and Subjective Well-being, 113-161.

LeBlanc, J. W. (2007). Pursuit of Virtual Life, Liberty, and Happiness and Its Economic and Legal Recognition in the Real World, The. Fla. Coastal L. Rev., 9, 255.

Locke, John (1894). An Essay Concerning Human Understanding. Edited by Alexander Campbell Fraser. 2 vols. Oxford: Clarendon Press.

Min, D., \& Kim, J. H. (2013). Is Power Powerful? Power, Confidence, and Goal Pursuit. International Journal of Research in Marketing, 30(3), 265-275.

Nietzsche, F. (1968). The will to power. Vintage.

Pearlstein, A. (2012). Pursuit of Happiness and Resolution of Conflict: An Agenda for the Future of ADR. Pepp. Disp. Resol. LJ, 12, 215.

Prasad, R. (2006). Your Chinese Horoscope. Fusion Books Publisher.

Ştiuliuc, D. (2011). The American Dream as the Cultural Expression of North American Identity. Philologica Jassyensia, 7(2), 363-370.

Swartz, D. (2012). Culture and Power: The Sociology of Pierre Bourdieu. University of Chicago Press.

Tate, M. J. (2007). Critical Companion to F. Scott Fitzgerald: a Literary Reference to his Life and Work. Infobase Publishing. 